\title{
Qlobal informasiya cəmiyyəti şəraitində Azərbaycan vətəndaşlarının adlandırılması məsələləri
}

\author{
Rasim Oliquliyev $^{1}$, Yedgar Cəfərov ${ }^{2}$, Ofruz Qurbanova ${ }^{3}$ \\ AMEA İnformasiya Texnologiyaları İnstitutu, Bak1, Azərbaycan \\ Idirector@iit.science.az, ${ }^{2}$ yedgar@yandex.ru, ${ }^{3}$ afruz1961@gmail.com
}

\begin{abstract}
Xülasə- Məqalə vətəndaşların adlandırılması sistemi və milli identiklik məsələlərindən bəhs edir. Azərbaycanda vətəndaşların adlandırılması ilə bağlı mövcud problemlər araşdırılmışdır. Qloballaşma dövründə, informasiya cəmiyyəti mühitində bu problemlərin mümkün həlli yolları nəzərdən keçirilmişdir. Azərbaycan vətəndaşlarının ad və soyadlarının, bu sahədə tarixi ənənələrin, ad strukturunun ətraflı təhlili aparılmışdır. Bu sahədə xarici təcrübə araşdırılmışdır. Problemlərin aradan qaldırılması istiqamətində təkliflər irəli sürülmüşdür.
\end{abstract}

Açar sözlor-ad, soyad, ata adı, toxəllüs, loqəb, adlandırma, ad sistemi, milli identiklik

\section{GIRIŞ}

Azərbaycanın qlobal informasiya məkanına sürətlə inteqrasiyası bir çox digər məsələlər kimi ad və soyad sistemi və milli identiklik məsələlərinin tədqiqatını da aktuallaşdırır. Xalqın tarixinin bir hissəsi olan insan adlarında xalqların həyatı, tarixi keçmişi, inancları, arzu və xəyalları, yaradıcılığı, sosial mühiti, əlaqələri və s. əks olunur [1]. Məlum olduğu kimi, qloballaşma prosesi bütün müsbət cəhətləri ilə yanaş1, xalqları öz milli xüsusiyyətlərini tədricən itirmək təhlükəsi ilə üz-üzə qoyur. Belə bir şəraitdə milli identikliyin qorunması, hüdudsuz və xaotik qlobal informasiya məkanında xalqın öz milli mənsubiyyətini asanlıqla ifadə edə bilməsi üçün təkmil, dayanıqlı və ardıcıl mexanizmlər formalaşdırılmalıdır.

Milli identikliyin əsas göstəriciləri bunlardır: xarici görünüş; ad; vətəndaşlıq; dil; inanc; adət-ənənə; mətbəx; musiqi və s. Bu xüsusiyyətlərdən də göründüyü kimi, hər bir xalqın tarixən formalaşmış ad sistemi böyük informativ yükə malik əsas milli identiklik göstəricilərindəndir. Çünki adlar, soyadlar və ata adları xalqların tarixi, milli psixologiyası, adətənənələri, məişəti, inanc sistemi, dünyagörüşü, elmi-mədəni səviyyəsi, istək və arzuları əsasında formalaşaraq inkişaf edir. $\mathrm{Bu}$ baxımdan, müasir dünyanın əsas reallığı kimi xalqları, mədəniyyətləri vahid informasiya-kommunikasiya mühitinə cəlb edən virtual məkanda hər bir azərbaycanlı üçün elə ortaq ad mühiti yaradılmalıdır ki, bu mühit təkcə fərd olaraq deyil, bir toplum olaraq da identikliyi təmin edə, xalqları, mədəniyyətləribir-birindən fərqləndirə bilsin.

Digər tərəfdən, məlum olduğu kimi, elektron dövlətin heç bir sferasını (e-səsvermə, e-təhsil, e-səhiyyə, e-ədliyyə, e- vergi, e-bank və s.) adlarsız təsəvvür etmək mümkün deyildir. Virtual məkanda yeni onomastik vahidlər (rəqəmsal antroponomik vahidlər) kimi çıxış edən PIN kodlar, e-poçt ünvanları, nickname-lər və s. çox zaman vətəndaşların real xüsusi adları əsasında formalaşdırılır. Digər tərəfdən, insanların real adları adi həyatda olduğu kimi onları elektron dövlət mühitində də identifikasiya edir. Ona görə də xüsusi adlarla bağlı bir sıra məsələlərin həlli, o cümlədən ad və soyad sisteminin təkmilləşdirilməsi, ad komponenti standartlarının yenidən işlənilməsi, adlardakı təhrif hallarının aradan qaldırılması, adların elektron bazalarının yaradılması və onlardan istifadə mexanizmlərinin işlənib hazırlanması, transliterasiya normalarının dəqiqləşdirilməsi, adların orfoqrafiyası qaydalarının nizama salınması və s. günün aktual problemlərindəndir.

\section{AZӘRBAYCANDA AD SISTEMININ FORMALAŞMASI TARIXİ}

Tarixin ibtidai dövrlərindən başlayaraq hər bir xalq1n özünəməxsus adlandırma ənənələri formalaşmışdır. Qədim türklərin, o cümlədən azərbaycanlıların da adlandırma sistemi spesifik xüsusiyyətlərə malikdir. Qədim türkdilli abidələr, o cümlədən “Orxon-Yenisey” kitabələri, M.Kaşğarinin "Divanilüğət-it-türk” əsəri, "Kitabi-Dədə Qorqud dastanları" və bir sıra etnoqrafik molumatlar türk xalqlarında adlandırma ənənələrinin çox qədimliyini və sistemliliyini göstərir [2,].

Aşağıdakı cədvəldə Azərbaycan milli soyad sisteminin inkişaf tarixi verilmişdir. tarixi

CəDVəL 1. Azərbaycan milli soyad sisteminin inkişaf

\begin{tabular}{|c|c|}
\hline $\begin{array}{c}\text { III-V əsr - h/h } \\
\text { Türk ad sistemi }\end{array}$ & -oğlu, -qIzı \\
\hline $\begin{array}{c}\text { VII-XVII əsrlər } \\
\text { (ərəb ad sistemi) }\end{array}$ & $\begin{array}{c}\text {-nisbə (i-vi), künyə } \\
\text { (əbu, ümm), nəsəb (ibn) }\end{array}$ \\
\hline $\begin{array}{c}\text { XIX əsr } \\
\text { (Fars ad sistemi) }\end{array}$ & -zadə \\
\hline XX əsr & ${\text {-ov²-yev²; -ski }{ }^{2} \text { və s. }}^{\text {(Rus ad sistemi) }}$ \\
\hline
\end{tabular}




\section{“Informasiya tohlükosizliyinin aktual multidissiplinar elmi-praktiki problemlori” IV respublika konfransı, 14 dekabr 2018-ci il}

\begin{tabular}{|c|c|}
\hline $\begin{array}{r}\text { 1988-h/h } \\
\text { (Müasir ad sistemi) }\end{array}$ & 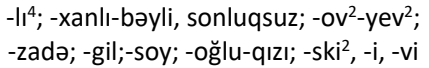 \\
\hline
\end{tabular}

Qeyd edək ki, müxtəlif xalqlarda nəsil adı ilə adlandırma ənənələri nə qədər qədim olsa da, "familiya (soyad)" termininin özü eramızın III-IV əsrlərində yaranmışdır. Latın dilində "ailə", "qohum-əqrəba", "qulluqçular da daxil olmaqla bütün evdəkilərin cəmini bildirən "familiya" ictimai-tarixi proses kimi IV əsrdə İngiltərədə, X-XI əsrlərdə İtaliyada, XVXVI əsrlərdə Danimarkada, XIV-XVIII əsrlərdə Macarıstanda, XVIII əsrdə Şotlandiya və İrlandiyada yayılmışdır. Familiya 1926-1934-cü illərdə Mustafa Kamal Atatürk tərəfindən Türkiyədə, təxminən eyni vaxtda İranda, 50-ci illərdə Misirdə, 1959-cu ildə Tunisdə rəsmiləşdirilmişdir [3].

Təşəkkül tapdığı ilk çağlardan yüksək sosial status nişanəsi, zadəganlıq göstəricisi sayılması familiyalara marağın artmasına və onların kütləviləşməsinə böyük təsir göstərmişdir. İlk vaxtlar familiyalardan adi insanlar deyil, daha çox zadəganlar istifadə edirdilər. Hətta qədim İngiltərədə yoxsul ailədən olan oğlanın zadəgan ailəsindən q1zla ailə qurarkən, q1zın familiyasını götürməsi ənənəsi vardı [2].

Rus ad sisteminə isə familiya 1703-cü ildə I Pyotrun hakimiyyəti zamanında tətbiq olunmuş və əsasən, dövlət xadimlərinə, knyaz və mülkədarlara verilmişdir. I Pyotr özü zadəganları fəxri ad kimi familiyalarla mükafatlandırırdı. Rusiyada familiyaların formalaşmasında türk mənşəli rus boyarlarının böyük rolu olmuşdur. Ona görə indi də rus ad sistemində türk mənşəli familiyalar əhəmiyyətli yer tutur [4].

XIX əsrə doğru Rusiyada cəmiyyətin sosial inkişafının təsiri ilə familiyalardan istifadə meyli tədricən kütləviləşdi. XIX əsrin sonu - XX əsrin əvvəllərində Rusiya imperiyasının tərkib hissəsi olan Azərbaycanda rəsmi sənədləşmə işlərinin rus dilində aparılması və bu zaman vətəndaşların soyadının ənənəvi qaydada oğlu, q1zı sonluqları ilə deyil, ov/-yev, -ova/yeva formantlarından istifadə etməklə rus familiyalarına bənzər onomastik vahidlərlə qeyd edilməsi xalqımız arasında bu cür familiyaların süni formada yayılmasına rəvac verdi. Həmin dövrdə Azərbaycanda -ov/-yev, -ova/-yeva formantlarının geniş yayılmasına əlverişli şərait yaratdı [5].

Azərbaycanın dövlət müstəqilliyinin bərpasından q1sa müddət sonra bu sahədə vəziyyətin nizamlanması məqsədilə Milli Məclisin "Azərbaycan Respublikası vətəndaşlarının soyadlarının dövlət dilinə uyğunlaşdırılması" haqqında 2 fevral 1993-cü il tarixli qərarına əsasən, Azərbaycan vətəndaşlarına soyadlarındakı -ov/-yev, -ova/-yeva sonluqlarını "zadə", -l14, "oğlu”, "qızı" formantları ilə əvəz etmək və yaxud öz soyadlarını sonluqsuz yazmaq imkanları verilmiş, Nazirlər Kabinetinin 12 may 2011-ci il tarixli qərarı ilə "Adın, ata adının və soyadın verilməsi və dəyişdirilməsi Qaydaları" təsdiqlənmişdir. Bununla belə mövcud reallıq, cəmiyyətimizdə adlar və soyadlar mühitinin hələ tam nizama düşmədiyini və qlobal şəraitdə xalqımızın milli identikliyi ilə bağlı yeni problemlərin ortaya çıxdığını göstərir [6].

Müstəqillik illərində, xüsusilə dünyaya yeni gələn körpələrin soyadlarında -ov/-yev, -ova/-yeva formantlarının çəkisi xeyli azalmışdır (Şəkil 1.) [7].

Amma bunun bir çox hallarda "zadə” və sonluqsuz formantlara istəklərin artması hesabına baş verməsi, eyni zamanda -ov/ -yev, -ova/ -yeva sonluqlarının hələ də qalması bu cür soyadları daşıyan vətəndaşlarımızın qlobal mədəniyyət müstəvisində digər türkdilli xalqlardan və başqa islam ölkələrinin vətəndaşlarından fərqləndirilməsində ciddi çətinlik yaradır. Azərbaycan Respublikası vətəndaşlarına verilən xarici (xidməti, diplomatik) pasportlarda ingiliscə -oğlu, -q1z1 sözlərinin yazılmaması və ata adının ingilis dilində göstərilməməsi isə vəziyyəti xüsusilə çətinləşdirir.

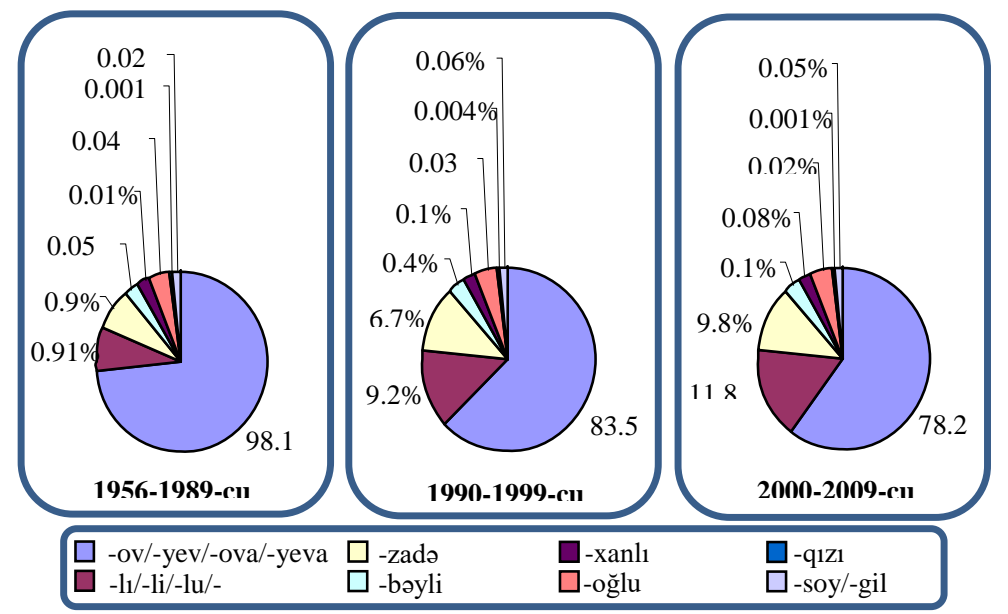

\section{MILLLI ADLANDIRMA SISTEMININ STRUKTURU}

Hazırda mövcud qanunvericilik aktlarının tətbiqi sayəsində ad və soyadların seçilməsi və qeydiyyatı prosesi sovet dövrünə nisbətən xeyli təkmilləşdirilsə də, bu sahədə bəzi problemlər hələ də qalmaqdadır.

Ad sistemi müxtəlif xalqlarda fərqli olur. Azərbaycanda ad sistemi biradlılıqdan çoxadlılığa doğru inkişaf etmişdir [5]. Məsələn, Tural (biradlı), Tural Oli oğlu (iki adlı), Tural Oli oğlu Məmmədli (üçadlı). Bəzi zəruri hallarda isə ayamalardan, ləqəblərdən istifadə edilirdi. Məşğul olduğu sənətin adını insana qoyur, yaxud onun hansisa əlamətindən ləqəb yaradırdılar (məs.: Dəmirçi, Pinəçi, Uzun, Gödək və s.).

Artıq Azərbaycan Respublikasının müvafiq qanunvericiliyi hazırda vətəndaşın yalnız bir adla, eləcə də ləqəblərlə, təxəllüslərlə qeydiyyata alınmasına imkan vermir. Belə ki, Azərbaycan Respublikası Mülki Məcəlləsinin 26.1-ci, eləcə də "Adın, ata adının və soyadın verilməsi və dəyişdirilməsi Qaydaları"nın 1.3-cü maddəsinə əsasən, hər bir fiziki şəxsin adı addan, ata adından və soyaddan ibarətdir [8]. 


\section{“Informasiya tohlükosizliyinin aktual multidissiplinar elmi-praktiki problemlori” IV respublika konfransı, 14 dekabr 2018-ci il}

Ofsuslar olsun ki, müvafiq normativ-hüquqi aktlarda təsbit edilmiş bu dəqiq ardıcıllığa rəğmən sənədləşmə zamanı həmin ardıcıllıq pozulur və bu sahədə dəqiq milli identiklik modeli (ad//ata adi//soyad strukturu) formalaşdırılmır. Məsələn, Azərbaycan Respublikasının vətəndaşlarına verilən şəxsiyyət vəsiqələrində soyad/ ad/ ata adı ardıcıllığından istifadə ounur.

Ad sistemimizdə müxtəlif təsirlərlə yaranmış nizamsızlığın aradan qaldırılmasına, ad/ ata adı/ soyad ardıcıllığının dəqiq norma kimi qəbul olunmasına və bütün sənədləşmələrdə adların vahid struktur üzrə yazılmasının təmin edilməsi hesabına sabit milli standartların möhkəmləndirilməsinə indi çox böyük ehtiyac vardır. Çünki Azərbaycanın ad sistemindəki mövcud vəziyyət, milli identikliyə xələl gətirməklə yanaşı, qlobal informasiya cəmiyyətində şəxsiyyətlərin eyniləşdirilməsini, həm ölkə daxilində, həm xaricdə fərdi məlumatlara çıxış imkanlarını da xeyli məhdudlaşdırır. Ogər nəzərə alsaq ki, hələ də transliterasiya problemi mövcuddur, onda problem daha da qabarıq şəkildə özünü büruzə verir.

\section{MILLİ ADLANDIRMA STRUKTURUNUN PSIXOLINQVISTIKK ASPEKTLORİ}

Yuxarıda qeyd olunanlarla yanaşı, ayrı-ayrı şəxsiyyətlərin həyat və fəaliyyəti, öz ad və soyadlarına qazandırdıqları tarixi mənalarla simvollaşan, eləcə də sosial-mədəni status, şöhrət, nüfuz və s. assosiasiyaları yaradan ad komponentləri vardır. Həmin komponentlərin sırasının pozulması onların ifadə etdiyi assosiativ mənaya da xələl gətirir. Məsələn, Üzeyir Hacıbəyli, Rəşid Behbudov, Həzi Aslanov ardıcıllığının insan təfəkkürünə ötürdüyü psixoloji informasiya Hacıbəyli Üzeyir, Behbudov Rəşid, Aslanov Həzi ardıcıllığının doğurduğu təsəvvürlə eyni deyildir, bu cür hallar çaşqınlıq yaradır.

Ad, ata adı və soyadların vahid milli standartının müəyyənləşdirilməsini zəruri edən digər mühüm amil də vardır. Məlum olduğu kimi, hazırda Azərbaycan qanunvericiliyi ölkə vətəndaşlarına şəxs adı və sonluqsuz soyad (Rəsul Rza), yaxud təxəllüs (Səməd Vurğun) və ya oğlu-q1zı formantları ilə yaradılmış soyadlarla (Emin Sabitoğlu) qeydiyyata alınmaq imkanı verir. Bu formalardan istifadə meyli kütləviləşdikcə ikinci komponentin hansı məna daşıdığını, yəni şəxs adınımı, şəxs adının bir hissəsinimi, ata adınımı, nəsil adımı, yoxsa təxəllüsmü olduğunu müəyyənləşdirməkdə, son nəticədə isə fərdi eyniləşdirməkdə çətinliklər yarana bilər. Ona görə də adlandırma sistemində komponentlərin hər birinin yeri dəqiq göstərilməlidir.

\section{BEYNӘLXALQ TӘCRÜBӘDӘ ADLANDIRMA SISTEMI}

Azərbaycanda fiziki şəxslərin bütün sənədlərdə qeydiyyatı proseslərinin ad/ ata ad1/ soyad, ata adının yazılması zəruri olmadıqda isə ad/ soyad ardıcıllığına əsaslanan dəqiq vahid standart üzrə həyata keçirilməsi beynəlxalq təcrübəyə uyğun olardı. Belə ki, bəzi ölkələrdə ilkin ad (first name), orta ad (middle name) və son ad (last name) komponentlərindən təşkil olunmaqla üçkomponentli modellərdən istifadə edilir.
İlkin ad (first name). İlkin ad doğularkən şəxsə verilmiş addır.

Orta ad (middle name). Qərb mədəniyyətinə görə, bəzən uşağa bir deyil, iki ad verilir. Bir sıra hallarda isə hətta üç ad qoyulmasına da rast gəlinir. Adətən, ikinci ad atanın, yaxud babanın, nənənin və ya ananın şərəfinə qoyulur və bu middle name kimi işlənir. Middle name şəxsə verilmiş adla yanaşı, soyadın da tərkibində ola bilər. İngiltərədə, Avstriyada, Kanadada, Yeni Zelandiyada, ABŞ-da və Birləşmiş Krallıqda əcdadların (ata, baba, ana, nənə) şəxs adlarından (forename) onların şərəfinə çox tez-tez middle name kimi istifadə olunur [9].

Danimarkada və Norveçdə isə middle name familiya anlamı daşıyır. Middle name kimi ananın qızlıq familiyası, yaxud əcdadlardan hansısa birinin last name-i seçilə bilər. Filippində middle name kimi, əsasən, ananın q1zlıq familiyasından istifadə olunur. ABŞ-da middle name-dən çox tez-tez abbreviatura formasında istifadə edilir. Məsələn, Mary Lee Bianchi - Mary L. Bianchi və s.

Son ad (last name və ya surname). Son ad şəxsin konkret bir ailəyə, nəslə mənsubluğunu bildirən ad komponentidir. Last name ifadəsinin sinonimləri familiya, yaxud ailə adıdır.

\section{ADLANDIRMA SISTEMİ İLə BAĞLI TEXNİKI HOLLOR}

Artıq dünyanın bir çox ölkələrində olduğu kimi, Azərbaycanda da biometrik pasportların və yeni nəsil şəxsiyyət vəsiqələrinin verilməsinə başlanmışdır. Qeyd edək ki, biometrik pasport - Beynəlxalq Mülki Aviasiya Təşkilatının (ing. International Civil Aviation Organization ICAO) müəyyən etdiyi biometrik məlumatlarla təchiz edilmiş pasportlardır. $\mathrm{Bu}$ pasportlar (ölçüləri, spesifikası, yazı qaydaları və s.) üzrə beynəlxalq standartlar da ICAO tərəfindən müəyyən olunur. Dünya təcrübəsində biometrik pasportlar həmçinin "e-pasport" və ya elektron pasport (ing. electronic passports) kimi də tanınır [10].

$\mathrm{Bu}$ pasportlarda adlandırma ilə bağlı texniki-hüquqi standartlar Beynəlxalq Mülki Aviasiya Təşkilatının "Maşınoxuyan səfər sənədləri" (Machine Readable Travel Documents) üzrə təlimatı əsasında tənzimlənir [11].

Təlimatda pasportun 2 zonası fərqləndirilir: 1) Vizual yoxlama zonası; 2) Maşının oxuduğu zona. Təlimatın 3.4-cü bəndi vizual yoxlama zonasında (şəkil 2) pasport sahibinin adının düzgün yazılışı ilə bağlı normaları nəzərdə tutur. 


\section{“Informasiya tohlükosizliyinin aktual multidissiplinar elmi-praktiki problemlori” IV respublika konfransl, 14 dekabr 2018-ci il}

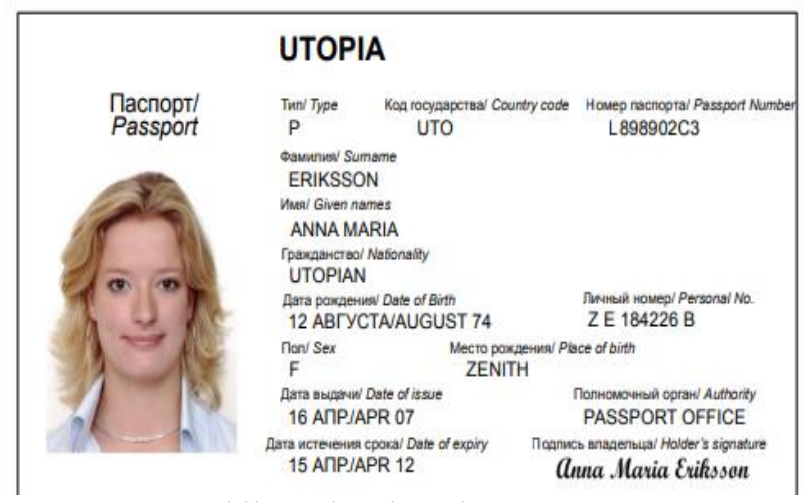

Şəkil 2. Vizual yoxlama zonası

$\mathrm{Bu}$ normalara görə pasport sahibinin adı iki hissədən ibarətdir: 1) əsas müəyyənedici ad; 2) ikinci dərəcəli müəyyənedici ad.

Təlimatın 4.6-cı bəndində isə maşının oxuduğu zonada (şəkil 3) pasport sahibinin adının düzgün yazılışı ilə bağlı normalar tasbit edilmişdir.

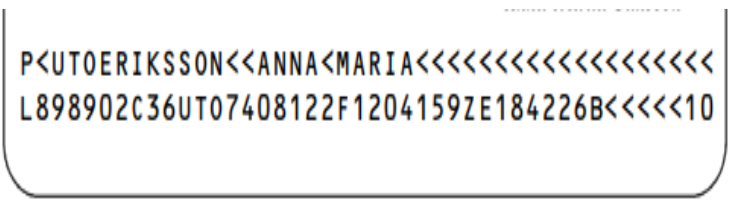

Şəkil 3. Maşının oxuduğu zona

Göründüyü kimi, biometrik pasportların və yeni nəsil şəxsiyyət vəsiqələrinin vizual yoxlama zonasında xalqımızın milli identikliyinin əsas antroponimik əlaməti kimi çıxıș edən "oğlu" və "qızı" sözlərinin yazılmasından ötrü heç bir hüquqi və texniki məhdudiyyət yoxdur.

\section{Nəтісə}

Aparılan təhlillər əsasında Azərbaycan Respublikasında adlandırma sisteminin təkmilləşdirilməsi həm ölkə daxilində, həm də qlobal informasiya məkanında xalqımızın milli identikliyinin təmin olunması məqsədilə aşağıdakı təkliflər irəli sürülür:

- Ölkə üzrə bütün sənədləşmə və qeydiyyat işlərinin aşağıdakı formatlar üzrə aparılması:

1) Komponentlərin hər birinin yazılması zəruri olduğu hallarda (Ad/ Ata adı/ Soyad formatı: Məmməd Həsən oğlu Rəhimov;

2) Ata adının yazılmasının zəruri olmadığı hallarda $\mathrm{Ad} /$ Soyad format1: Məmməd Rəhimov;

3) Ata adı inisialının göstərilməsinin zəruri olduğu hallarda: Ad/ Ata adının ilkin hərfi/ Soyad formatı: Məmməd H. Rəhimov.
- Beynəlxalq aləmdə fərdin milli identifikliyinin təmin olunması məqsədilə Azərbaycan Respublikası vətəndaşlarına verilən biometrik pasportlarda və yeni nəsil şəxsiyyət vəsiqələrində həm Azərbaycan, həm də ingilis dilində addan sonra ata adının daxil edilməsi və mütləq "oğlu" və "qızı" sözlərinin əlavə olunmasi;

- biometrik pasportlarda və yeni nəsil şəxsiyyət vəsiqələrində ingilis dilində transliterasiya normalarının pozulması hallarının qarşısının alınması məqsədilə adlandırma sisteminə transliterasiya standartlarının (cədvallərinin) (az-en, en-az) əlavə olunmasi;

- Qeyd edilən məsələlər üzrə ən optimal texniki həllərin tətbiqi üçün bu məsələlərin Beynolxalq Mülki Aviasiya Təşkilatı ilə işçi qaydada müzakirəsinin təşkil edilməsi.

$\mathrm{Bu}$ gün yeni inkişaf mərhələsində tarixi nailiyyətlər qazanan, qlobal proseslərin fəal subyektinə çevrilən Azərbaycan dövlətinin adlar vasitəsilə xalqın milli identikliyinin ifadəsi məsələsini yenidən nəzərdən keçirməsi, Azərbaycançılıq ideologiyası çərçivəsində, tarix və müasirlik işığında bu problemin optimal həlli yollarının tapılması xalqımızın gələcəyinə, informasiya cəmiyyətinin inkişafına, milli şüurun, özünüdərk hissinin daha da yüksəlişinə töhfə olardi.

\section{ӘDӘBIYYAT}

[1] Л.Э.Аблитарова, «Формирование имен и фамилий у различных народов, проживающих на территории Крыма», Современная филология: материалы IV Междунар. науч. конф., г. Уфа, 2015, с. $19-21$ https://moluch.ru/conf/phil/archive/137/7511/

[2] H.Ә.Həsənov, "Familiya sosial-ictimai hadisə kimi”, Azərbaycan onomastikası problemlərinə həsr olunmus III elmi-nəzəri konfransın materialları, Bakı, APU, 1990, s. 9 - 11

[3] A.Paşa, "Azərbaycan antroponimiyasının leksik problemləri”, Bak1, "Maarif”, 1997, 253 s.

[4] Н.А.Баскаков, «Русские фамилии тюркского происхождения», Баку, “Язычы”, 1992, 280 с

[5] M.N.Çobanov, "Azərbaycan antroponimiyasının əsasları", Bakı, "Maarif", 1998, $332 \mathrm{~s}$

[6] Y.Cəfərov, "Azərbaycan dilinin onomastikası müstəqillik dövründə”, Bak1, "Elm və təhsil”" nəşriyyat1, 2015, 367 s.

[7] “Adlar və Soyadlar” Dövlət İnformasiya Sisteminin yaradılmas Konsepsiyası. AMEA-nın İnformasiya Texnologiyaları İnstitutu, Ekspress-İnformasiya, Bakı, 2010, 49 s.

[8] Azərbaycan Respublikası Nazirlər Kabinetinin Qərarı, Bakı şəhəri, 12 may 2011-ci il, http://www.e-qanun.az/framework/21676

[9] The Use of Middle Names, http://www.genfiles.com/articles/middle-names/

[10] https://az.wikipedia.org/wiki/Pasport

[11] Machine Readable Travel Documents, Seventh Edition, 2015, Part 3: Specifications Common to all MRTDs, ICAO, $86 \mathrm{p}$ https://www.icao.int/publications/Documents/9303_p3_cons_en.pd 
ISSUES OF AZERBAIJAN CITIZENS NAMING IN THE CONTEXT OF THE GLOBAL INFORMATION SOCIETY

Rasim Alguliyev ${ }^{1}$, Yedgar Jafarov ${ }^{2}$, Afruz Gurbanova ${ }^{3}$ Institute of Information Technology of ANAS, Baku, Azerbaijan

Idirector@iit.science.az, ${ }^{2}$ yedgar@yandex.ru, 3 afruz1961@gmail.com
Abstract - The article is devoted to the issues of the naming system and national identity. Attention is paid to the current name problems in Azerbaijan. The article considers negative cases caused by these problems in the era of globalization and the information society environment. A wide scientific analysis of Azerbaijani names and surnames, historical traditions in this field, names structure and so on is carried out. Specific proposals are given in order to solve these problems.

Keywords - name, surname, patronymic, pseudonym, nickname,naming system, nationalidentity 